\title{
The Potential Role of PPPs in Developing a Sustainable SME Sector in Developing Countries: A South
} African Experience ${ }^{1}$

\author{
Patrick Mabuza \\ National Energy Regulator of South Africa, Pretoria, South Africa \\ Patrick.mabuza@nersa.org.za
}

\begin{abstract}
The introduction of Public-private Partnerships (PPPs) in infrastructure provision has changed the way in which governments around the world now view infrastructure provision. However, the introduction of PPPs to deliver infrastructure has not benefited the broader public. Although SMEs are important for employment creation, inequality and poverty reduction, the participation of SMEs (small and medium enterprises) in PPP projects is very low in developing countries. This is because PPP models in developing countries are developed based on those used in developed economies, and such models ignore the socioeconomic realities facing developing countries. The objective of this study is therefore to demonstrate that PPP projects in developing countries present an opportunity for growing the SME sector and create the needed jobs and contribute to poverty alleviation. The study has found that PPP projects have the potential to develop a sustainable SME sector, as it has found that SMEs do participate in PPP projects; however, their participation is curtailed by a number of challenges such as: lack of access to finance, limited human resources, low technological capabilities, and lack of access to markets. It also found that linking SMEs to PPP projects may address some of these challenges to a certain extent, especially if SMEs provide services to PPP projects during both the implementation and the operational phases of PPP projects. It also found that PPPs have not yet been identified by the South African government as one of the initiatives that can facilitate SME development. Most focus on PPP projects is only on ensuring that they include ownership by previously disadvantaged South Africans. The study recommends that a policy be developed that will incentivise PPP firms to use SMEs in their projects and penalise those PPP firms that fail to comply with the policy imperatives. It went on and found that the different South African government institutional initiatives or frameworks to support SMEs seem to be adequate; however, what is needed is a cohesive approach that links all these initiatives together and ensures that they support one another.
\end{abstract}

Keywords: Small medium enterprises, public-private partnerships (PPPS), unbundling, PPP models, subcontracting

\section{Introduction}

The introduction of PPPs in infrastructure provision has changed the way in which governments around the world now view infrastructure provision. However, the introduction of PPPs to deliver the needed infrastructure has benefited only a few firms. Most of these firms are the big construction companies that possess technological know-how and those that have the financial ability to execute large infrastructure projects. Although SMEs are important for employment creation, inequality and poverty reduction, the participation of SMEs (small and medium enterprises) in these PPP projects is very low in many countries. This is because PPP models in developing countries are developed based on those used in developed economies, and such models ignore the socio-economic realities facing developing countries, like unemployment, income inequality and poverty. Therefore, this study argues, PPP projects in developing countries present an opportunity for growing the SME sector. Although the lack of public infrastructure to provide public services is seen as a problem by many governments, it presents an opportunity for the development of a sustainable SME sector for developing countries. The bigger the infrastructure backlog, the bigger the opportunity for countries to develop a viable SME sector that has the potential to create jobs and alleviate poverty, while at the same time addressing the challenge of inequality.

\footnotetext{
${ }^{1}$ Disclaimer: The views and opinions expressed in this article are those of the author and do not necessarily reflect the official policy or position of the National Energy Regulator.
} 
The study challenges the viewpoint of seeing infrastructure backlogs as a problem that only provides opportunities to big private sector companies and argues that infrastructure backlogs can be used by governments to reduce the triple challenges of unemployment, poverty and inequality by linking SMEs to PPP projects. The traditional PPP model that is being applied by many developing countries does not fully encourage the participation of SMEs in PPP projects, as most of the projects executed through this model are bundled into big projects that SMEs cannot execute, due to lack of technological know-how and weak balance sheets. The objective of this chapter is therefore to demonstrate how PPPs, especially during construction and operational phases, can be used to develop a sustainable SME sector and address the triple problem of unemployment, poverty and inequality. The study is organized as follows: the second section discusses infrastructure and SME development, the third section discusses the study methodology, while the fourth section gives the analysis of the study survey and the last section concludes and gives recommendations.

\section{Literature Review}

Infrastructure backlog an opportunity for SME development: SMEs differ from large organisations in many ways. SMEs differ from big enterprises in resource limitations, in their informal strategies and flexible structure. As a result, SMEs have a higher failure rate compared to large firms. This causes a slow growth of SMEs, especially in developing countries (Hussain et al., 2012). The lack of key resources, such as human capital, finance and technology, affects their growth. The question that one can ask is: can PPPs address these challenges? The answer is: not all SME challenges can be addressed through PPPs; however, PPPs can improve the sustainability of SMEs through subcontracting them to provide certain goods and services. In that way the challenge of access to markets for SME's goods and services would have been mitigated to a certain extent, as SMEs would have a guaranteed market for their products and a sustainable income as long as the PPP project continues to operate. This means that more PPP projects in a country can result in more opportunities for SMEs. This can happen only if the PPP market is supported by a well-functioning legal, regulatory and institutional system that supports the growth of the PPP market, thus opening more opportunities for SMEs to sell their goods and services to the growing PPP market. This also requires a policy that would force PPP project firms to use SMEs as suppliers of their goods and services.

The question that one would ask is "why use SMEs to create jobs, reduce income inequalities and poverty through PPP projects instead of using big firms?" The answer to this question is that SMEs create new jobs through small investments opportunities that may not be attractive to large companies, thus maximising local economic opportunities; SMEs use local raw materials that would otherwise be neglected; they offer people with little income and little education opportunities to develop and contribute meaningfully to the economy; they provide a route through which previously disadvantaged persons can own and control a larger percentage of the economy; and more SMEs means more of the wealth generated by them stays within the country to be used further to generate even more opportunities, compared to large firms which normally repatriate their profits to their country of origin (Mutsigwa, 2009; Fatoki and Odeyemi , 2010). Compared to larger firms, SMEs tend to use less capital per worker, as most SME activities are more labour-intensive compared to big firms. A study in countries such as Ghana, Colombia and Malaysia found that small firms have significantly higher value added to fixed assets ratio (Hussain, 2000).

With regards to SME opportunities in the South African PPP market, it is projected that South Africa's infrastructure may not meet future demand for infrastructure needs (NEPAD Business Foundation, 2012). South Africa's infrastructure deficit was estimated at R1,5 trillion in 2012 (NEPAD Business Foundation, 2012). In the 2012 budget speech, the Finance Minister, Pravin Gordhan, announced that R850 billion would be allocated to infrastructure investment over the next two years. The projected cost of the South African government's infrastructure programme over the next 30 years is estimated to be R4,3 trillion (Paton, 2013). This backlog cannot be automatically converted into opportunities for SMEs and the country as a whole without government's intervention. The high rate of unemployment in the country of approximately $24,3 \%$ in 2014 has increased to $27.1 \%$ in quarter 3 of 2016 and to $27.7 \%$ in the first quarter of 2017 (Republic of South Africa. Statistics South Africa, 2014a and 2016).The high level of poverty, which is estimated to be about $45,5 \%$ of the population living on less than R620 per month in 2011, and high inequality levels as expressed by a Gini-coefficient of 0,65 in 2011, present a big challenge for the country (Republic of South Africa. 
Statistics South Africa, 2014b). However, the infrastructure backlog presents an opportunity for the country to effectively address these triple challenges of unemployment, poverty and inequality. What the government needs to do is to find a way of changing its infrastructure backlog problems into opportunities for job creation and poverty alleviation and develop a policy that will encourage or force companies involved in PPP projects to use SMEs as their suppliers of intermediate goods and services. A clear plan of how this should be done also needs to be developed.

SMEs and economic development: Before discussing the role of SMEs in economic development, it is imperative to first define SMEs as the term is defined differently from one jurisdiction to another.

Defining SMEs: There is still no universally accepted definition of SMEs. Even though SMEs constitute the central pillar of all economies, there is still no single definition in the literature on SMEs for which global consensus is assured. Although the South African National Small Business Act of 1996, amended in 2003 and 2004, gives an official definition for SMEs in South Africa, different agencies and research institutions do not use this definition consistently and that makes it difficult to benchmark different studies and data on SMEs (Republic of South Africa. National Credit Regulator, 2011). The most common definition of SMEs is based on the number of employees that a firm may have or the turnover that the company generates in a year. According to the National Small Business Act of 1996, as amended in 2004 (Republic of South Africa. Department of Trade and Industry, 2004), an SME is defined as:

“... a separate and distinct business entity, including co-operative enterprises and nongovernmental organisations, managed by one owner or which, including its branches or subsidiaries, if any, is predominantly carried on in any sector or sub-sector of the economy mentioned in Column 1 of the schedule..."

The National Small Business Act of 1996, as amended in 2004, also distinguishes between survivalist, micro, very small, small, and medium enterprises; hence the use of the word SMMEs. However, the term SMMEs and SMEs are used interchangeably in South Africa. Even for the purpose of this study, the two terms are used interchangeably. The broad definition of SME in SA is summarised in Table 1.

Table 1: Broad definition of SMMEs in the SA National Small Business Act

\begin{tabular}{|c|c|c|c|}
\hline Enterprise & Number of employees & Annual turnover (Rands) & $\begin{array}{l}\text { Gross assets, excluding fixed } \\
\text { property }\end{array}$ \\
\hline Medium & $\begin{array}{l}\text { Fewer than } 100 \text { to } 200 \\
\text { depending on industry }\end{array}$ & $\begin{array}{l}\text { Between R4 million and R50 } \\
\text { million depending on industry }\end{array}$ & $\begin{array}{l}\text { Between R2 million andR18 } \\
\text { million depending on industry }\end{array}$ \\
\hline Small & Fewer than 50 & $\begin{array}{l}\text { Between R2 million and R25 } \\
\text { million depending on industry }\end{array}$ & $\begin{array}{l}\text { Between } \mathrm{R} 2 \text { million and } \mathrm{R} 4 \\
\text { million depending on industry }\end{array}$ \\
\hline Very small & $\begin{array}{l}\text { Fewer than } 10 \text { to } 20 \\
\text { depending on industry }\end{array}$ & $\begin{array}{lrr}\text { Between } & \text { R200000 } & \text { and } \\
\text { R500 000 } & \text { depending } & \text { on } \\
\text { industry } & & \end{array}$ & $\begin{array}{lrr}\text { Between } & \text { R150 } 000 & \text { and } \\
\text { R500 000 } & \text { depending } & \text { on } \\
\text { industry } & & \end{array}$ \\
\hline Micro & Fewer than 5 & Less than R150 000 & Less than R100 000 \\
\hline
\end{tabular}

Source: Falkena, Abedian, Blottnitz, Coovadia, Davel \& Madungandaba (2000).

The role of SMEs in economic development: SMEs face challenges that make them vulnerable and prevent them from attaining growth, especially when they have to participate in PPP projects. These problems range from lack of human resources development and technological capability, to access to markets and finance. If left alone, SMEs would always find it difficult to penetrate local PPP markets. SMEs are vital for the development of an economy of any country, especially in the developing world. SME contribution to economic development is through job creation and poverty reduction (Hussain et al., 2012). They provide the potential for women and other traditionally disadvantaged groups to gain access to work under better conditions, to be productive, sustainable and have access to quality employment opportunities (Al-Dairi, McQuaid \& Adams, 2012). Sometimes it is not feasible for large firms to produce the goods and services they need as inputs in their production process. The fact that SMEs manufacture these products makes them vital for any economy, as they function as suppliers of intermediate inputs to local firms. It is worth noting that SMEs are faced with the need to overcome significant challenges such as access to finance, skill development and access to 
markets; however their strategic importance cannot be overemphasised. According to Al-Mubaraki and Aruna (2013), the following are some of the roles that SMEs play in an economy: (a) they are responsible for growing employment at a faster rate than large organisations; (b) they increase the competitive intensity of the market and reduce the monopolistic positions of large organisations; and (c) they encourage the deployment of entrepreneurial skills and innovation. SMEs are therefore effective job creators and are sources of income for a big proportion of a country's population. They provide on-the-job training opportunities and important basic services for disadvantaged people (UNIDO, 2007). SMEs are a primary vehicle through which new entrepreneurs provide economies with a continuous supply of innovative ideas and skills.

According to Hussain et al. (2012), the main reason why governments worldwide support SMEs is because SMEs are believed to be making substantial contributions to aggregate economic growth. The contribution of SMEs to economic growth and development is significant. For example, a study by the Economic Survey of Pakistan from 2007-2009 found that in Pakistan, SMEs account for more than 95\% of the total number of businesses, and $80 \%$ of employment outside agriculture. In Bangladesh, SMEs are estimated to contribute about $50 \%$ of industrial GDP and provide employment to about $82 \%$ of the total industrial sector employment. In Nepal, 98\% of industrial establishments are SMEs, while in India they contribute 30\% of GDP (Hussain et al., 2012). In Chile, SMEs contribute about $20 \%$ of GDP and about $60 \%$ of employment. In Malaysia they contribute about 31\% to GDP and 58\% to employment (Timm, 2012). In Turkey, SMEs account for $95,5 \%$ of businesses operating in the manufacturing sector and provide $66,1 \%$ of employment. In Ghana, SMEs represent about $92 \%$ of businesses and contribute about $70 \%$ to GDP (Abor and Quartey, 2010). In Malawi, they contribute about 38\% to employment. In China, SMEs are responsible for about $60 \%$ of output and $75 \%$ of employment (Akugri, Bagah \& Wulifan, 2015). In Africa and Asia (excluding China), SMEs are estimated to be responsible for about $90 \%$ of both rural and urban enterprises (Akugri et al., 2015).

To demonstrate that SMEs are imperative for economic growth and development, a regression analysis by Banerjee (2014) which used World Bank's Business Environment Survey (WBES) data collected between 1999 and 2000 in advanced economies, found that employment growth is around 9\% greater for SMEs compared to large firms, even after controlling for firm age. The study also found that the employment growth for young firms less than five years old was estimated to be around $18 \%$ higher than that of older firms. Although this last point refers to firm age, in many cases young firms are more likely to be SMEs. Another study that analysed the employment potential of SMEs using Pakistan's census of manufacturing industries data for the fiscal year 2005/2006, was conducted by Batool and Zulfiqar (2011). The study found that the elasticity of substitution between labour and capital was 1,1137, showing that capital and labour are strong and very good substitutes in the production process of the SME sector in Pakistan. This means that, if the price of capital increases while the price of labour remains constant, the quantity of labour will be substituted for capital, and employment may be generated by SMEs in Pakistan. Criscuolo, Gal and Menon (2014) further supported the above findings about employment creation by small firms. Analysing data from 18 countries with developed economies covering the period 2001-2110, they found that young and small firms created far more jobs compared to big and old firms for all 18 countries included in the study. The above findings further confirm the employment generation potential of SMEs.

According to available statistics, in South Africa, SMEs contribute between 27\% and 34\% of GDP and about $55 \%$ of all employment (Timm, 2012; Joubert, Schoeman, \& Blignaut,1999). Table 2 shows the contribution of SMEs in the South African economy. The table shows that the number of SME establishments is high (99,3\%); however, their contribution to GDP is low. The reason for their small contribution to GDP may be attributed to the fact that most SMEs operate at the survivalist and micro-level, thus their contribution to GDP is small. Linking SMEs to PPPs may improve their contribution to GDP and to gross capital formation as this has the potential of moving SMEs from micro-level to at least medium-sized enterprises, and that can change SMEs' investment behaviour to reflect their contribution to GDP. 
Table 2: Contribution of SMEs in the South African economy²(2004)

\begin{tabular}{ll}
\hline Contribution to & Percentages \\
\hline GDP & 34 \\
Employment & 54 \\
Number of firms & 99 \\
\hline
\end{tabular}

Falkena, Hawkins, Llewellyn, Luus \& Masilela (2004)

A study by Abor and Quartey (2010) estimated that about $91 \%$ of formal business entities in South Africa are SMEs and these SMEs contribute about 52 to $57 \%$ of GDP and about $61 \%$ to employment. As mentioned earlier, data on SMEs in South Africa is not consistent from one author to another and that makes it difficult to know the exact SME figures in the country.

A First National Bank study on total entrepreneurship activity (TEA) in $\mathrm{SA}^{3}$, showed that South Africa's TEA in 2008 stood at 7,8\% compared to Brazil 12\%, India 11,5\%, Colombia 24,5\%, and Mexico 13,1\% (First National Bank, 2010). This is an indication that a lot still needs to be done in South Africa to promote entrepreneurship. As already stated, one way of promoting entrepreneurship is linking small businesses to PPP projects to provide them with sustainable business opportunities. SMEs can provide services such as cleaning services, facility management, laundry, IT, maintenance, catering and other services, depending on the nature of the PPP project. In terms of fostering successful new businesses, South Africa is far behind a number of countries like Ghana, Brazil, Zambia and Chile and ranks 35 out of 54 countries that participated in a Global Entrepreneurship Monitor survey of 2010 (Morgan, 2012). Table 3 shows selected countries' ability to foster successful new businesses.

Table 3: Ability to foster successful new businesses (2010 figures \%)

\begin{tabular}{llllll}
\hline & South Africa & Ghana & Zambia & Brazil & Chile \\
\hline Start up & 5 & 11 & 17 & 6 & 11 \\
New businesses & 4 & 25 & 17 & 12 & 6 \\
Established & 2 & 25 & 13 & 15 & 6
\end{tabular}

businesse

Source: Morgan (2010)

Given the fact that South Africa has implemented a number of PPP projects in the past decade and that many more PPP projects are still in the pipeline, South Africa needs to take advantage of these PPP projects and use them to develop its SME sector in order to address its triple challenges of unemployment, poverty and inequality. SME development through PPP projects will not happen without support from the public sector, and that is why linking SME development to PPP projects is vital and needs to be made a government policy. In the absence of a government policy that will compel PPP project firms to use SMEs in providing them with intermediate goods and services, it will be difficult to achieve a reasonable number of SMEs' participating meaningfully in PPP projects.

Challenges facing SMEs: Due to their size, SMEs face problems that make them vulnerable to macroeconomic changes and prevent them from attaining growth, as many business opportunities accrue to big firms, because they enjoy economies of scale and scope. International literature identifies lack of access to finance, human resources, access to markets and access to technology as the main constraints that hinder SME development in many developing countries (OECD, 2006; Ayyagari, Demiurge-kunt Vojislav, 2008; Subrahmanya, 2012).

Lack of finance: Adequate financing is required to help SMEs set up and expand their operations, develop new products and invest in new staff or production facilities (OECD, 2006). An empirical work by Fjose, Grunfeldand Green (2010)shows that about $48 \%$ of SMEs in sub-Saharan Africa identify access to finance as

2Statistics on South African SMEs are very old as currently there is no organisation that collects SMEs' data at national level.

${ }^{3}$ Measured by a Total Entrepreneurship Activity (TEA) index, which looks at the percentage of the active population (people between 25 and 64 years), who are entrepreneurs in a given country. 
one of the major constraints to their expansion. This finding is also supported by other studies such as those conducted by the South African National Credit Regulator (2011);Falkena et al. (2004) and AL-Mubaraki and Aruna, (2013).Access to financial institutions is important for SMEs. A survey undertaken on financial constraints of the sector in Fiji found that a bank loan was important for SMEs. This was confirmed by the number of SMEs that would have loved to take a bank loan for business expansion. Of those SMEs interviewed and were without a bank loan, $77 \%$ indicated that they would borrow from a bank, if they could, in order to expand their operations. However, an adverse perception regarding loan requirements, cost structures and lack of collateral appeared to keep them away from the banks (Sharma and Gounder, 2012; African Development Bank, 2012;Ayyagari et al., 2008). This finding is supported by Fatoki and Odeyemi (2010), who postulate that, out of 445 SMEs interviewed in South Africa, 406 applied for a bank loan, but only $27 \%$ were successful. This shows that access to finance is a problem with many SMEs. A study by SEDA (2012) also confirmed this finding.

Human resources: Human resources consist of education and training provided to employees. Educated employees are not only efficient and productive, but are also innovative. Human resources are a critical feature in the success of any business (Kumar, 2012). As Lall (1992) asserts:

"... technical competence of an industrial workforce is improved by education imparted by various formal training systems and by in-firm training".

SMEs that employ highly skilled employees are likely to be more efficient, as they may increase productivity by producing a higher level of output or by producing output of greater value (Cooke, 2000). The fact that SMEs operate in a constantly changing environment due to globalisation requires a workforce that has attained a certain level of education (Al-Dairi et al., 2012). Lack of human resources is a major constraint in SME development (Salleh, Kasolang \& Jaffar, 2012; SEDA, 2012; Lall, 1992:166). An empirical study by Salleh et al. (2012:343) conducted in 2012 on total quality management in Malaysia found that the ability to perform work is supported by training and development programmes, job and placement, systematic job development and career planning. In many circumstances SMEs do not have the resources to provide such skills, as they are operating at a smaller scale compared to big businesses that benefit from economies of scale and scope. This finding is supported by an empirical study by Tan and Batra (1996), which analysed the relationship between firm size and its likelihood to provide training to its employees, which found that larger firms are more likely to provide training to their employees compared to small businesses. The same study also looked at mean years of education of the workforce and the proportion of the workforce that is skilled. The results showed that an educated workforce is more likely to receive training than a less educated one. This shows the difficulties that SMEs are facing in terms of up-skilling their workforce. Other studies that support the importance of human resources in SMEs businesses include Lee (2001) and Hussain et al. (2012). In order to facilitate the participation of SMEs in PPP projects, human development should be an important factor for SMEs, as nowadays infrastructure projects in general involve the use of advanced technologies which local SMEs may not be familiar with. For SMEs to participate fully in PPP projects, they must have the know-how of the latest technologies.

Low technological capabilities: Technological capabilities are imperative for SME competitiveness. Technological innovation is regarded as a tool for strengthening the competitiveness of a nation, as it helps in improving productivity (Lee, 2001). The increase in the amount of goods and services produced can be achieved through the use of new technologies that reduce production input costs while increasing output per unit of input employed (Tan and Batra, 1996). Improving technological capabilities by SMEs can go a long way in improving their profits which are imperative for the future expansion of any business. Technological capabilities benefit SMEs in several ways, namely by enhancing SME efficiency, reducing costs, allowing speedy communication with customers, eliminating traditional supply constraints, and broadening market reach, both locally and internationally (Subrahmanya, 2012; Hussain et al., 2012).

The knowledge and capabilities of SMEs to adopt technological innovation is limited due to the fact that financial institutions and governments are less supportive to SMEs (AL-Mubaraki and Aruna, 2013). An empirical work by Pitt and Lee (1980) showed that larger firms are more efficient than small firms because they possess technological know-how. Collaboration between SMEs and PPPs can play a critical role in trying 
to address these constraints, as technological capabilities can be transferred from a PPP's workforce to SME employees involved in PPP projects. This can happen because PPPs would set service standard targets for SMEs. For SMEs to meet these standards, they will be forced to improve their technological know-how.

Access to markets: Access to markets by SMEs is one of the major constraints that hinder the development of the SME sector in developing countries (Hussain et al., 2012). Even if SMEs can have all the right human capital, access to finance and technological know-how, they can still fail if they do not have access to markets. Large firms and the public sector are reluctant to deal with small businesses that do not have a track record of meeting clients' expectations; as a result SMEs are reluctant to participate in public tenders because they are normally unsuccessful. For example, a study conducted in 2007 to evaluate SMEs' access to public procurement markets in the European Union revealed that SMEs, in particular micro- and small enterprises, are on average under-represented in public procurement. The amount of public contracts awarded to SMEs does not reflect SMEs' overall weight in the EU economies (European Commission. DG Enterprise and Industry, 2010).

SMEs lack marketing skills and also lack information about participating in international markets. For a firm to penetrate a market, it needs to have information about the market it wants to penetrate and also marketing skills (UNIDO, 2007). SMEs struggle to penetrate big markets because in such markets they get exposed to a more complex and risky business environment compared to larger firms, due to poor resources or lack of resources (OECD, 2004; Al-Mubaraki and Aruna, 2013). If SMEs were to be given an opportunity to work with PPPs, they will gradually improve their efficiencies and develop to bigger firms that can effectively compete in international markets.

Having discussed the challenges faced by SMEs, the question that one can ask is: Can PPPs address these SME challenges mentioned above? The answer to this question is that PPPs can address these problems but cannot eliminate them completely, as SMEs and government will also need to play their respective roles. However, PPPs have the potential to make SMEs attractive to banking institutions and financial markets, as PPPs can provide a constant market for the goods and services produced by SMEs, thus creating a sustainable revenue stream. PPPs can contribute to technological skills transfer to SME employees involved in PPP projects. Involving SMEs in PPP projects can put SMEs in a better position to expand their operations to other sectors of the economy, as they may acquire the resources required to get involved in other ventures.

Table 4: SA policy and institutional framework for SME support

\begin{tabular}{|c|c|c|}
\hline Department & Agency & Mandate \\
\hline \multirow{3}{*}{$\begin{array}{l}\text { Department of Trade and } \\
\text { Industry }\end{array}$} & Enterprise & To support small business development \\
\hline & $\begin{array}{l}\text { Development } \\
\text { (SEDA) }\end{array}$ & \\
\hline & Empowerment & To fund black-owned businesses and \\
\hline \multirow{4}{*}{$\begin{array}{l}\text { Department of Economic } \\
\text { Development }\end{array}$} & $\begin{array}{l}\text { National Small Business } \\
\text { Advisory Council }\end{array}$ & $\begin{array}{l}\text { To advise the Minister on ways to boost } \\
\text { support for small businesses }\end{array}$ \\
\hline & Khula Finance Limited & $\begin{array}{l}\text { To supply funding to small businesses. } \\
\text { To bridge the funding gap in the SME } \\
\text { market not addressed by commercial } \\
\text { financial institutions }\end{array}$ \\
\hline & $\begin{array}{l}\text { Industrial } \\
\text { Corporation }\end{array}$ & $\begin{array}{l}\text { To fund industrial projects, but small } \\
\text { business funding forms a bigger part of its } \\
\text { mandate. }\end{array}$ \\
\hline & $\begin{array}{l}\text { SA Micro-finance Apex Fund } \\
\text { (Samaf) }\end{array}$ & $\begin{array}{l}\text { To facilitate the provision of affordable } \\
\text { access to finance by micro, small and } \\
\text { survivalist businesses }\end{array}$ \\
\hline $\begin{array}{l}\text { Department of Science and } \\
\text { Technology }\end{array}$ & $\begin{array}{l}\text { Technology } \\
\text { Agency (TIA) }\end{array}$ & $\begin{array}{l}\text { To fund innovation for big and small } \\
\text { businesses }\end{array}$ \\
\hline
\end{tabular}




\begin{tabular}{lll}
\hline The Presidency & National & Youth \\
Development Fund & $\begin{array}{l}\text { To assist the youth with career skills and } \\
\text { to help start their own businesses. }\end{array}$ \\
Micro-Agricultural Financial & $\begin{array}{l}\text { To help the working poor's ability to run } \\
\text { Institute of South Africa }\end{array}$ & $\begin{array}{l}\text { existing agriculture businesses, to start } \\
\text { new ones and be able to develop these } \\
\text { into fully commercial operations. }\end{array}$ \\
\hline
\end{tabular}

Sources: Republic of South Africa. National Credit Regulator (2011)

South African government's initiatives to support SMEs: The South African government has implemented a number of institutional initiatives that are aimed at supporting the development of the SME sector. The government established SME support agencies such as Ntsika, which then became the Small Enterprise Development Agency (SEDA), and Khula Enterprise Finance to provide funding to SMEs. It also created the Apex Fund that provides microfinance loans of less than R10 000. It passed the Small Business Act in 1996, while the broad-based black economic empowerment (BBBEE) codes also stipulate how SMEs should be addressed by big companies (SBP, 2009). Other initiatives include the establishment of the Umsobomvu Youth Fund, which now is part of the Youth Development Fund, tasked with promoting job creation, entrepreneurship and skills development for the South African youth. The Industrial Development Cooperation (IDC) also provides funding to SMEs, although its main focus is developing big industrial projects. All these initiatives have not yet yielded the expected national outcome of increasing employment and reducing poverty and inequalities. Since they were implemented, the country's SME sector's development is still lagging behind in terms of its contribution to GDP and employment, compared with the SME sectors of other developing countries. The main agencies and funds of the South African government supporting SMEs are found in five different national departments as listed in Table 4 above. The idea of linking SMEs to PPP projects that is being advocated in this paper is expected to build on top of these other government initiatives, as these initiatives aim to address other SME challenges that cannot be fully addressed by PPP projects. As can be seen from the above table, there is currently no support for SMEs from the National Treasury PPP Unit.

The potential role of PPPs in addressing challenges faced by SMEs: In general, PPPs represent cooperation between the public and the private sector with the intention to develop infrastructure networks and at the same time provide public services. So far there is no research that the author is aware of, on the involvement of SMEs in PPP projects. However, Hussain et al. (2012) define PPPs for SMEs as:

"... an approach to addressing SMEs' growth problems through the combined efforts of public, private, and developmental organisations.'

This definition does not talk about the involvement of SMEs in PPP projects but refers to institutional programmes led by both the public and private sectors that can help address SME challenges. PPPs can be the main users of goods and services produced by SMEs. As SBP (2009) asserts:

"... one of the most obvious and surprising untapped ways that companies can support developmental objectives in countries and communities in which they operate is through spreading economic opportunities through a variety of small enterprise development, training and business linkage initiatives."

This is the role that large PPP projects should play in economies of developing countries. PPPs should use SMEs to provide them with the services they need, while at the same time supporting SMEs with the necessary skills. Many PPP models for developed and developing countries do not mention the use of SMEs as potential suppliers of PPP goods and services, and they do not embed SMEs into their PPP models. One of the reasons may be that SMEs lack the technical, financial and technological ability to deliver services required by PPPs, as these services may be required on a larger scale. This may be true if the services required by PPPs are bundled. In a case where these services are unbundled, SMEs have the potential to respond positively to PPPs' requirements. Another reason could be that involving an SME in a PPP can be time-consuming, and at the end it can increase the PPP project implementation costs, as this may involve a complex structuring of the project. The problem with involving too many stakeholders in a project is that it can complicate the allocation of responsibilities, such as who does what, what is the role of state officials, what is the role of the SME and what is the role of the private sector partner in the PPP (Ansell Gash, 2007). This is one of the risks that the 
state and the private partner may need to manage so that the risks do not negatively affect the private partner involved in the PPP project.

In many cases, a PPP is only formed by a private firm and the public agency responsible for the development of the infrastructure asset. Although the South African PPP regulations do not prescribe the size of the private sector partner, in most cases, if not all, the private partner is one of the big local or international construction companies. This model has overlooked the potential that PPP projects can have in developing a sustainable SME sector that can create jobs for the unemployed and generate income for the poor, while at the same time addressing the challenge of infrastructure backlog. The role of PPPs in developing the SME sector is also acknowledged by Paolo (1992). As Paolo asserts, "Although having SMEs as subcontractors in big PPP projects is understood as an area of potential growth for developing countries, there is yet no discussion about SME involvement in PPP projects in many countries."For PPPs to contribute to the development of the SMEs sector, there should be a policy that will enforce strong partnerships between government, PPPs and SMEs to the benefit of all parties. For example, when the expanded public work programme (EPWP) started in 2004, its target was to create one million jobs and 3000 SMEs by March 2009. The EPWP exceeded its target by creating 1,617 million jobs, and created 4325 SMEs by the end of March 2009 (Republic of South Africa. Department of Public Works, 2009). The infrastructure sector exceeded its target and achieved 127\%. It out-performed all sectors involved in the EPWP programme. Although most of the jobs created through this programme were short-term this, however, gives an indication that, if the private sector works together with the public sector to create jobs, a lot can be achieved.

It is worth noting that creating jobs through infrastructure using SMEs has its own challenges. These challenges are due to the fact that jobs created through infrastructure projects are short-term in nature, especially during the construction phase of the projects. However, during the operational phase of a PPP project, a number of jobs remain long-term. The other challenge is that SMEs are more likely to utilise labourintensive production methods, and such methods are slow and produce poor quality work compared to capital intensive methods used by big firms. There is also a high risk of projects captured for patronage purposes, as was detected during the first and second phases of the EPWP. During the implementation of the first two phases of the EPWP, there were accusations that the selection of EPWP participants was hijacked by politicians for patronage purposes (Republic of South Africa. Department of Public Works, 2014). This may also happen when SMEs are used to create jobs through participating in PPP projects. One may find that only SMEs that have a strong link with politicians get opportunities to participate in PPP projects. There is also a high possibility of fronting, in the sense that big PPP firms may create their own small companies that will participate in PPP projects as SMEs. If not addressed properly, this can sabotage the whole idea of using PPP projects to develop sustainable SMEs that would create jobs, alleviate poverty and reduce inequality.

Most debates in the PPP arena are about finding the best way of using the private sector to deliver public infrastructure, but little has been said about using PPPs to develop SMEs and create jobs for the poor. This is the missing link that governments can use to boost job creation through SME development. The advantages of PPPs have been advocated only to be in the transfer of financial and non-financial risks to the private party, cost savings, enhanced asset quality and service levels provided to the public, freeing up fiscal funds for other areas of public expenditure, etc. (Republic of South Africa. National Treasury, 2004). The development of the SME sector using PPP projects has been ignored by the traditional PPP model followed by most developing countries. As Hussain et al. (2012) assert, PPPs are a source of developing businesses in developing countries. They can be used to address developing countries' socio-economic challenges. For this to happen, there should be a change in the way developing countries see PPP projects. PPPs should be structured in such a way that they benefit (a) the public in general through job creation or development of the SMEs sector, (b) the public sector through the provision of the required infrastructure and (c) the private sector through the continuous business opportunities provided by the long-term nature of PPP contracts. Quite often the general public do not feel or think they benefit much from PPP projects, as the current PPP model tends to favour the private sector partner more than the public as a key stakeholder of a PPP project.

In order to ensure that PPPs benefit a wider group of beneficiaries, there is therefore a need for developing countries to develop their own PPP model that will talk or respond to their economic, political and social 
challenges. The current practice of many developing countries is such that they model their PPP projects on PPP models of developed countries. These models fail to take into account the socio-economic conditions of developing countries. The question is how PPPs can assist in developing a sustainable SME sector for developing countries. This can happen when the public and the private sectors jointly bring funding and other resources to implement PPP projects through a Special Purpose Vehicle (SPV). The SPV can then contract SMEs to provide it with the necessary services required by the PPP projects. In this case, the SME is guaranteed of a market for its products and a continuous income for the duration of the PPP concession. The current practice in the South African PPP market is such that the SPV should meet the country's BBBEE requirements. Although small businesses participation in a PPP project is mentioned in the National Treasury PPP Manual, the main emphasis, however, is on black ownership of the SPV (Republic of South Africa. National Treasury, 2004). A PPP collaboration that brings together the public sector, private sector and the SME sector has a better chance of being more effective in fighting poverty, unemployment and inequalities, which are the most worrying challenges of many developing countries. Such an approach has a huge potential to contribute to the radical economic transformation agenda of the country.

PPP projects normally involve big international organisations who possess the know-how of project and business management. SMEs, on the other hand, are small business operations with limited resources such as human capital, technological know-how and access to finance, as mentioned earlier. Linking SMEs with PPP projects that involve international organisations can provide other opportunities for SMEs, such as technological transfer, better human capital formation, deeper international trade integration, and more competitive local SME firms (Klein, Aaron and Hadjimichael, 2001; UNECA, 2009). International studies, such as those by Elibariki (2007) and the World Bank (2004), found that organisations that involve foreign firms as foreign direct investors (FDIs) have a positive impact on productivity and efficiency, and therefore on poverty. FDIs do not only bring extra capital but also lead to technological transfer, better human capital formation, deeper international trade integration, a more competitive business environment and increased tax revenue, to name just a few (Klein et al., 2001; UNECA, 2009). All these add to poverty reduction strategies through increased private consumption. Having discussed the potential role of PPPs in addressing SMEs challenges, the following section gives an analysis of South African experience on SMEs' participation in PPP projects, based on a survey conducted by the author.

\section{Methodology}

The information used to analyse the participation of SMEs in PPP projects in South Africa was collected by the Author using a questionnaire between February 2015 and April 2015.Both quantitative and qualitative information was collected from 14 PPP projects. These PPP projects came from different sectors. Data was collected only from operational PPP projects. These PPP projects were the only projects that met the sampling criteria, which focused on PPPs that had operated for at least a year. Data was collected from three respondents per PPP project. These respondents were, namely, the public sector partners, the PPP firms themselves, and the SMEs that provided services to the PPP projects. A total of 54 responses were targeted for both the private and the private sectors. The questionnaire was developed using Survey-Monkey, and a link to the questionnaire was emailed to each respondent. The response rate from these respondents was $61 \%$. A second questionnaire was drawn up, which aimed at collecting specific information from SMEs, and targeted both private sector PPP firms and public sector agencies that administered PPP projects. Five more public sector and 13 more SME responses were received from the supplementary survey.

\section{Results}

The analysis is mainly focused on the participation of SMEs in PPP projects in South Africa, and the challenges that SMEs and PPP firms face when SMEs are contracted to provide goods and services to PPP project firms (concessionaire or the SPV). Through a desk top research the author identified a number of activities or tasks that could be executed by big firms and by SMEs in a PPP project as shown in table 5 below. Note that the list in the table is not exhaustive. 
Table 5: Summary of activities for big firms and SMEs

\begin{tabular}{|c|c|c|}
\hline & Activities at the implementation phase & Activities at the application phase \\
\hline \multirow{8}{*}{$\begin{array}{l}\text { Activities to be } \\
\text { allocated to big } \\
\text { firms }\end{array}$} & Big firms implementation experts & Big firms application experts \\
\hline & Engineering design of asset & Major asset maintenance \\
\hline & Construction of asset & IT system maintenance \\
\hline & Construction of bridges & Major equipment maintenance \\
\hline & Refurbishment of existing asset & replacement \\
\hline & Major IT system installation & etc. \\
\hline & Security (for prison PPPs) & \\
\hline & Medical equipment etc. & \\
\hline \multirow{11}{*}{$\begin{array}{l}\text { Activities to be } \\
\text { allocated to SMEs }\end{array}$} & SME implementation experts & SME application experts \\
\hline & Consulting services & Minor asset maintenance and replacement \\
\hline & Road markings & Toll collection/billing services \\
\hline & Road signs installation & Tow-truck services (road PPP) \\
\hline & Road rail installation & Road marking \\
\hline & Security services & Guard rail replacement \\
\hline & Construction of toll offices & Road signs replacement \\
\hline & Furniture provision & Security \\
\hline & Plumbing services & Furniture provision \\
\hline & Electrification services & Catering \\
\hline & Supply of construction materials etc. & Laundry, Cleaning etc. \\
\hline
\end{tabular}

Source: Author

Although activities or tasks during the implementation phase are short term, services required by PPP firms during the operation or application phase are long-term in nature and that provides sustained opportunities for SMEs.

Services outsourced by PPP firms during the operational phase: Table 6 shows some of the services that are currently outsourced by South African PPP firms during the operational phase of PPP projects. Information on the implementation phases of the project was difficult to find, due to the fact that most of the people which were involved during the implementation phase were no longer working for the PPP project firms during the study period. Most of the PPP project firms covered in the survey outsourced certain services to SMEs. The only PPP that did not outsource its services to SMEs was the nature conservation PPP. PPPs that outsourced five out of the six identified possible services at the operational stage of the projects are office accommodation and hospital PPPs. It can be argued that these PPPs have a high potential for providing SMEs with opportunities, as well as having a high potential for job creation, followed by roads and prisons PPPs. Although roads PPPs only outsource four of the six services identified, roads PPPs have the highest potential for job creation compared to other PPPs, given the fact that road construction and operation is more labour-intensive than any of the PPPs listed in Table 6 below.

Table 6: Services outsourced during the operational phase of PPP projects

\begin{tabular}{lllllll}
$\begin{array}{l}\text { Types of services } \\
\text { that can be provided } \\
\text { by SMEs to PPPs }\end{array}$ & Road & $\begin{array}{l}\text { Nature } \\
\text { conservation }\end{array}$ & $\begin{array}{l}\text { Water and } \\
\text { sanitation }\end{array}$ & Prison & Hospital & $\begin{array}{l}\text { Office } \\
\text { accommodation }\end{array}$ \\
\hline Maintenance & $\mathrm{X}$ & - & $\mathrm{X}$ & $\mathrm{x}$ & $\mathrm{x}$ & $\mathrm{x}$ \\
Catering & - & - & $\mathrm{X}$ & $\mathrm{x}$ & $\mathrm{x}$ & $\mathrm{x}$ \\
Laundry & - & - & - & $\mathrm{x}$ & $\mathrm{x}$ & $\mathrm{x}$ \\
Security & $\mathrm{X}$ & - & $\mathrm{X}$ & $\mathrm{x}$ & $\mathrm{x}$ & $\mathrm{x}$ \\
IT & $\mathrm{X}$ & - & $\mathrm{X}$ & - & $\mathrm{x}$ & $\mathrm{x}$ \\
Tolls/tariffs collection & $\mathrm{X}$ & - & $\mathrm{X}$ & - & - & - \\
\hline
\end{tabular}

Source: Survey conducted by Author

$X=$ means the service is provided by SMEs, - =means there is no service provided SMEs 
Size of enterprises providing services to PPPs during the operational phase: Figure 1 shows different types of enterprises that provide services to PPP projects during their operational phase. Most of the services $(79,2 \%)$ are provided by SMEs and big firms. About $17 \%$ of the respondents indicated that SMEs provide services to PPP projects they worked for, while only $4 \%$ of PPPs indicated that their services were provided only by big private firms, and there were no services provided by foreign companies. This is a good indication that local companies have the ability to provide services to PPPs as this is the only way to ensure that local SMEs benefit from PPP projects.

\section{Figure 1: Types of enterprises providing services to PPPs (\%)}

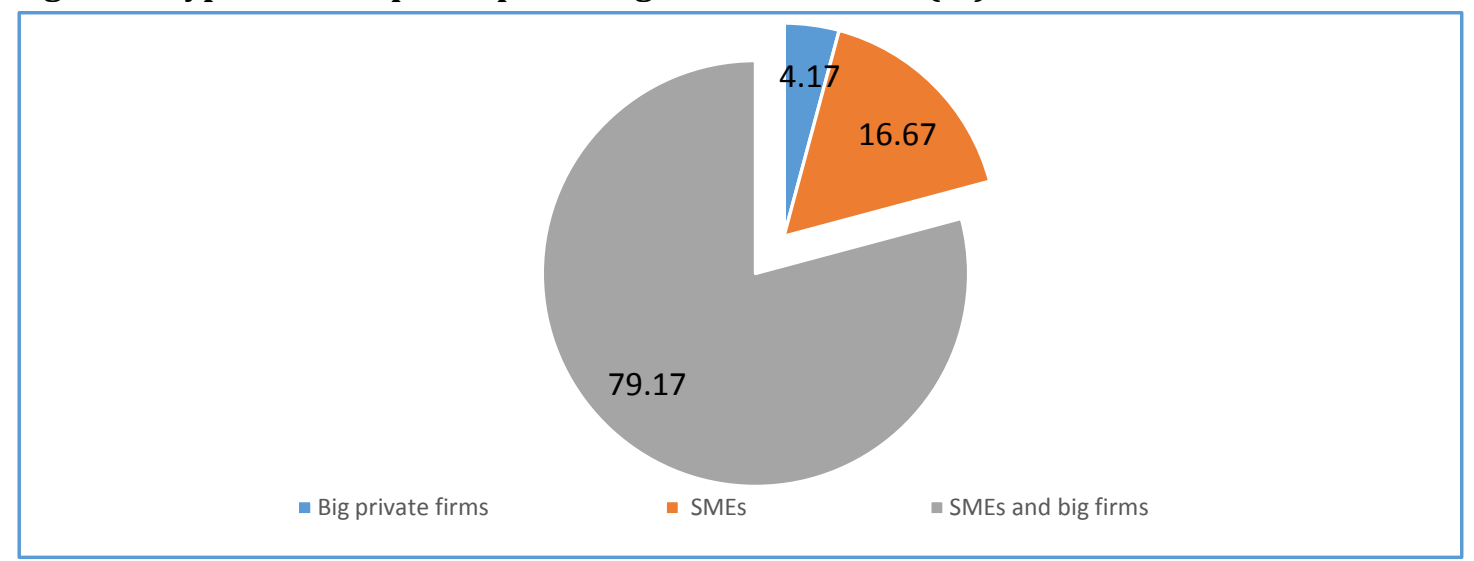

Source: Survey conducted by Author

Although the majority of PPP project firms outsource their services to both big and small firms (79,2\%), the bigger share of these services is provided by big firms. Figure 4 shows in detail to what extent PPP services are provided by SMEs and big firms.

Factors considered by PPP firms when awarding contracts to SMEs: Figure 2a shows the different factors considered by PPP firms when awarding contracts to SMEs. About $46 \%$ of PPP firms appoint SMEs as service providers based on fitness for purpose, meaning there are no lighter requirements for SMEs compared to big firms when awarding a contract to provide services to PPPs. SMEs have to compete with large firms for tenders under the same requirements or conditions. About $37 \%$ of the respondents indicated that their companies allocate contracts to SMEs because some of the tenders that PPP firms secure from the public sector have conditions that require them to subcontract SMEs. However, this requirement is not for SMEs, but for historically disadvantage individuals' (HDIs) compliance. Given the fact that most firms owned by HDIs are SMEs, many respondents see this requirement as an SME requirement. When the PPP firms' respondents were asked if their approaches to using SMEs vary depending on the geographical location of the project, the majority (54\%) of them indicated that this category did not apply to them, while $46 \%$ said their approaches vary, based on the geographical location of the project. Figure $2 \mathrm{~b}$ gives the different factors considered by those who vary their approaches to using SMEs if the project is in a different geographic area. It is worth noting that about $46 \%$ of the respondents do not consider any factor for awarding tenders to SMEs, as they indicated that the factors listed were not applicable to them. 
Figure 2: Priority given and factors considered when awarding contracts to SMEs

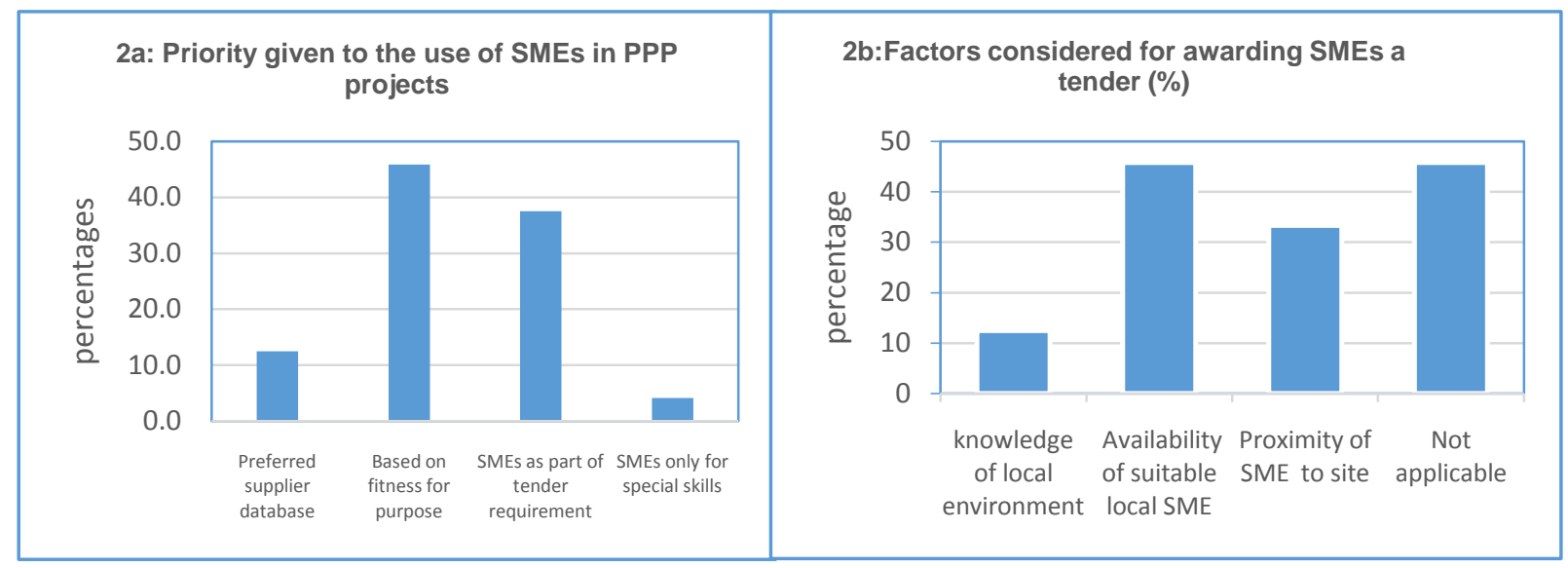

Source: Survey conducted by Author

Target for contracts to be awarded to SMEs: Figure 3a shows that most PPP firms have targets for awarding contracts to SMEs. However, it has been found during the survey that the target that respondents referred to, was not meant for SMEs, but for HDI owned companies, which happen to be SMEs, as discussed earlier. The target that the respondents referred to was the $10 \%$ which is one of the requirements of the Preferential Procurement Regulations of 2001. The Public Finance Management Act (PFMA) requires that all bids awarded by a public entity should be awarded to companies that comply with the Preferential Procurement Regulations requirements. The Preferential Procurement Regulations of 2001 require that not more than 10 percentage points be awarded to companies that are owned by HDIs or subcontract HDI-owned companies. Therefore indirectly there is a target for SMEs. Figure 3a shows that the majority of PPP firms set a target of between 0 and $20 \%$ for SMEs, and the target becomes smaller as one moves towards higher percentage shares. About $42 \%$ of the respondents indicated that targets for contracts to be awarded to SMEs do not apply or are not applicable to their PPP firms. Figure $3 \mathrm{~b}$ shows that the share in rand amount of contracts that are awarded to SMEs is high at the lower percentage band and becomes lower (in percentages) as one moves towards the higher percentage bands. This confirms that SMEs get a smaller share from a PPP contract and this is not good for developing a sustainable SME sector.

Tools used by PPP firms to engage with SMEs: Figure 4a shows that most PPP firms make SMEs aware of business opportunities through supplier databases or through adverts in the media. The most commonly used tools, as shown in Figure 4b, are the list of approved SMEs or supplier databases and local area directory of suppliers. It is possible that these tools are not only used to engage with SMEs but also to engage with big firms. About $44 \%$ of the respondents indicated that they do not use any tool to create awareness about SME opportunities in their respective PPP firms. Making SMEs aware of available PPP opportunities is very important if we were to develop a sustainable SMEs sector by increasing their participation in PPP projects. PPP project firms should find other ways of making sure that SMEs are aware of opportunities within their companies. The proportion $(43,5 \%)$ of PPPs that do not use any tool to advertise opportunities available for SMEs within their companies is worrying and should be reduced by encouraging them to use some of the commonly used tools like media and local area directory. 
Figure 3: Targets for awarding contracts to SMEs

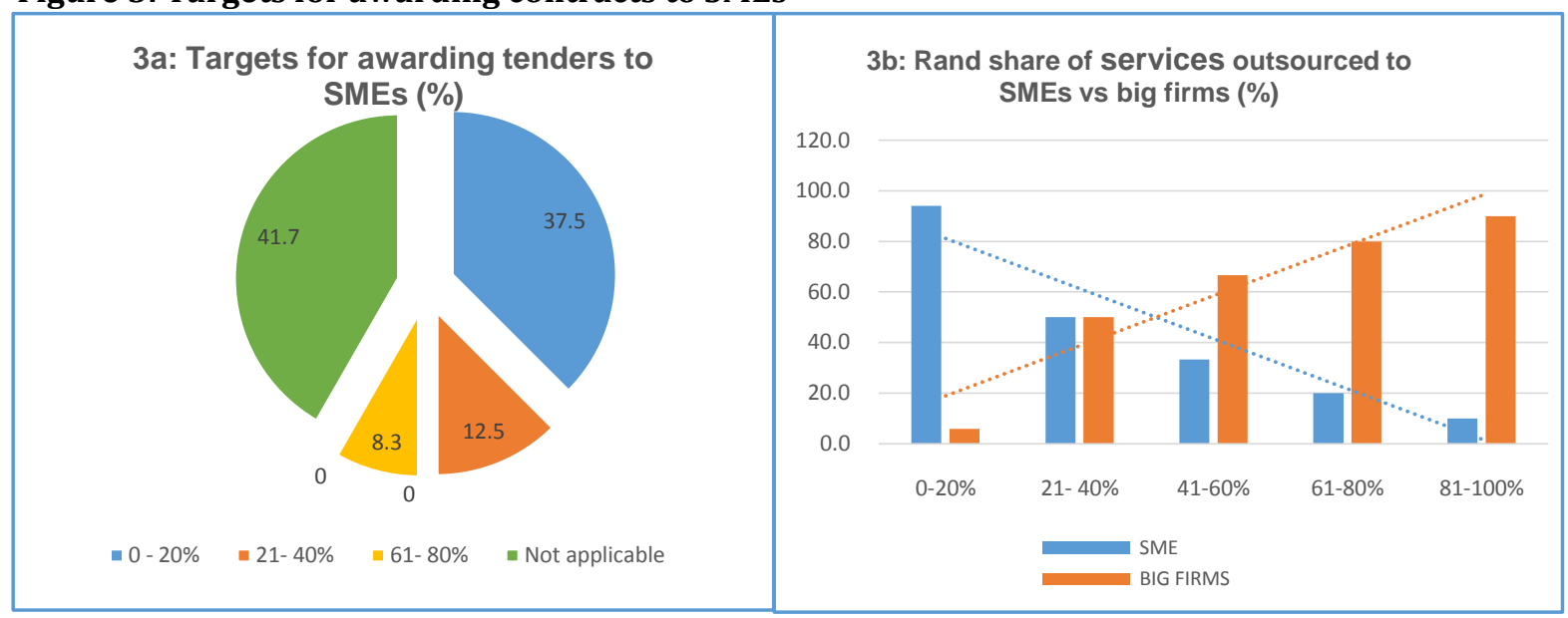

Source: Survey conducted by Author

Figure 4: Ways and tools used by PPP firms to engage with SME

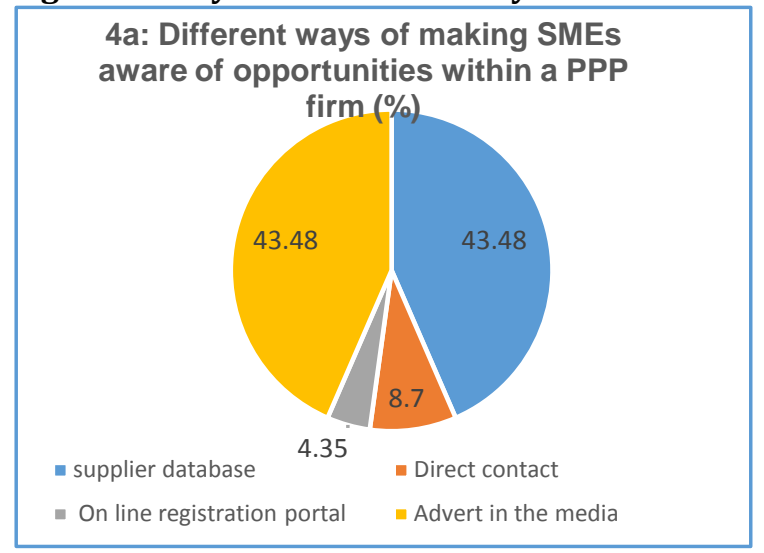

4b:Tools to assist PPPs engage with SMEs for tenders (\%)

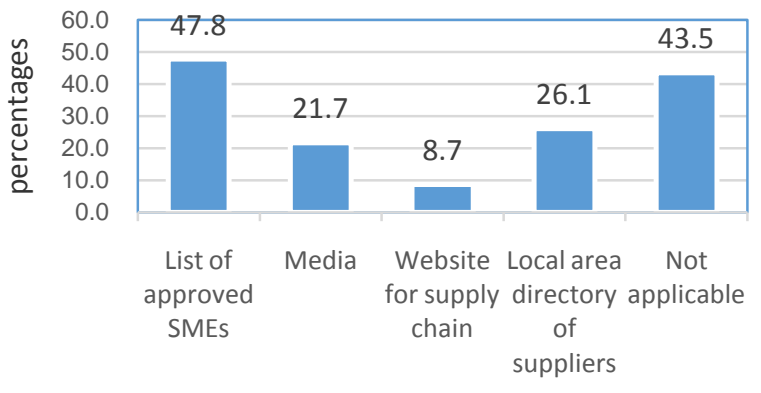

Source: Survey conducted by Author

Challenges and causes of challenges in using SMEs in PPP projects: The questionnaire also focused on collecting information on the different challenges that PPP firms face when dealing with SMEs in a PPP project. It also analysed data on the different ways in which the challenges could be overcome in order to increase SMEs' participation in PPP projects.

Challenges faced by PPP firms when using SMEs: Figure 5a shows the different challenges that PPP firms face when dealing with SMEs. When respondents were asked whether their firms face challenges with provision of services by SMEs, about $87 \%$ of respondents indicated that their PPP firms do face challenges when working with SMEs. The most worrying challenge they face is poor service quality delivered by SMEs, followed by failure by SMEs to deliver the service on time (see Figure 5a). This finding is also confirmed by literature on SMEs, in that SMEs struggle to deliver services of high standard on time due to lack of human capacity. In addition to the above challenges, Aigbavboa and Thwala (2014) investigated challenges and problems facing SMEs involved in construction in Mbombela (Nelspruit) and found that lack of managerial planning, technical know-how, financial skills and job opportunities are the main challenges facing SMEs in the construction industry. Brink, Cant and Ligthelm (2003) also investigated problems experienced by small businesses, focusing on SMEs operating in townships and CBD areas in Gauteng in 2003, and found that inflation, interest rates, competition, technology change and credit management were also of particular concern for the success of SMEs. 
Causes of challenges and their possible solutions: The main reason why SMEs encounter the problems mentioned above is lack of appropriate management skills. Figure $5 \mathrm{~b}$ shows that about $80 \%$ of the respondents indicated that poor management of SME firms is the main cause of the problems. The second main cause is lack of appropriate human resources, followed by lack of access to finance. Lack of appropriate technology and poor relationship between SMEs and PPP firms respectively were not identified as major problems. The majority of respondents think finding ways to improve managerial skills of SMEs should be a priority, followed by providing SMEs with training to improve the quality of the skills of their employees. Although access to technology is also seen as a hindrance, respondents did not consider acquiring relevant technology as a high priority area that needs immediate attention by SMEs.

Figure 5: Type and causes of SME challenges

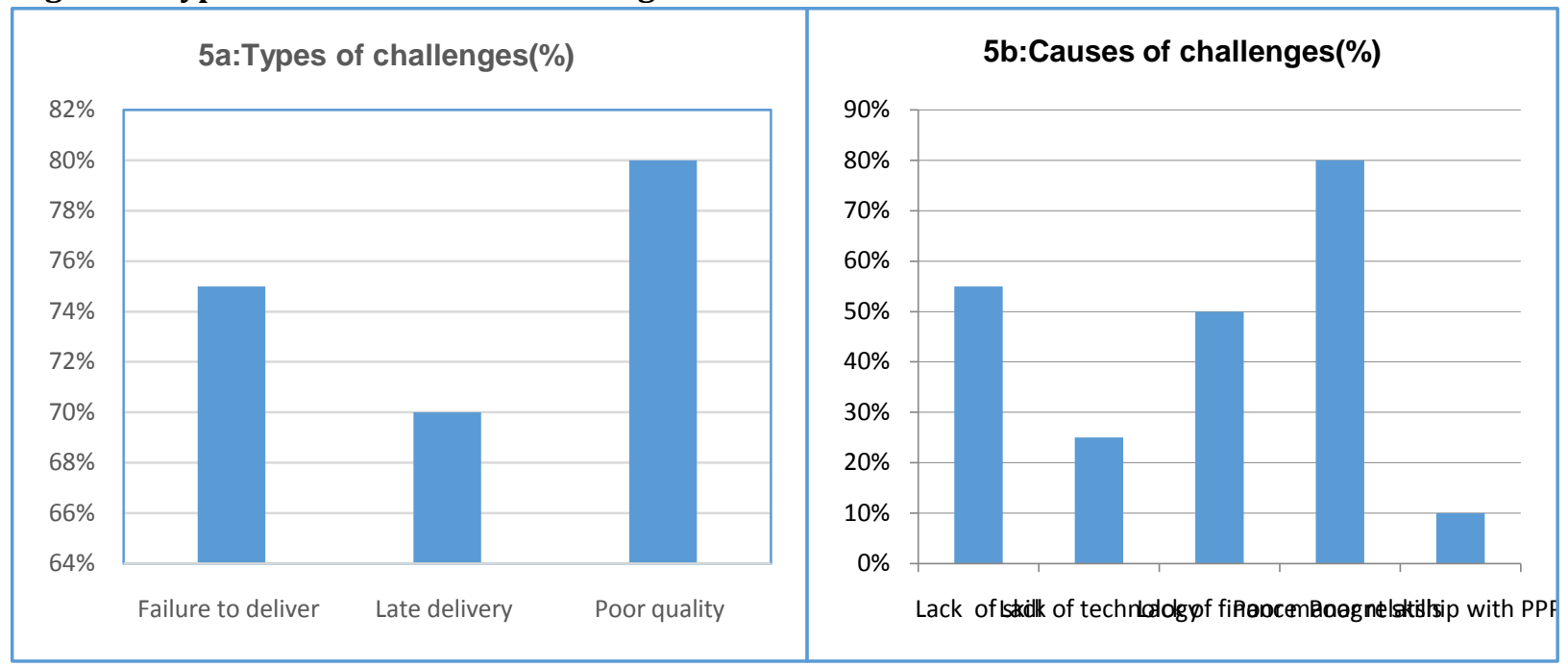

Source: Survey conducted by Author

Figure 6: Rating of factors affecting SMEs' performance (\%) ${ }^{4}$

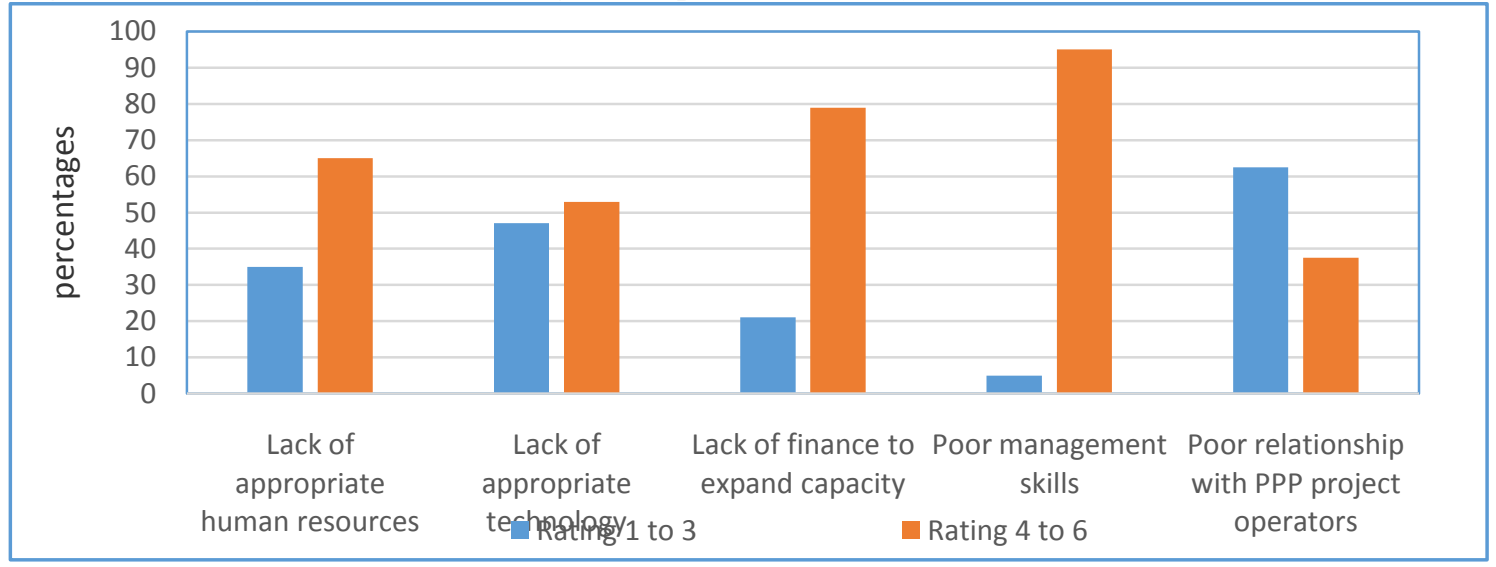

Source: Survey conducted by Author

Respondents were also asked to rate (from 1 to 6) the impact of the causes of the challenges faced by PPP firms when using SMEs to provide services. The results of the ratings are presented in Figure 6, where a rating of 1 means less significant impact and a rating of 6 means significant impact. Poor management skills for SMEs have a significant impact on the performance of SMEs. About $95 \%$ of the respondents who answered this question gave this factor a rating of 4 to 6 , and only $5 \%$ of the respondents gave it a rating of 1 to 3 . The

${ }^{4} \mathrm{~A}$ rating of 1-3 means less significant to medium impact, while a rating of 4-6 means significant impact 
next significant factor was lack of finance, followed by lack of appropriate human resources. Poor relationship with PPP project operators had no significant impact on the performance of SMEs. The rating of the challenges is consistent with the results presented in Figure $5 \mathrm{~b}$ above. It is important for policy makers to be aware of these challenges and their causes, in order to devise a strategy that would mitigate or eradicate these challenges through policy intervention. Eradication of these challenges is paramount for effective participation of SMEs in PPP projects. Given all the challenges faced by SMEs, however, SMEs providing services to PPP firms in this country do create jobs and the jobs created have shown an increase over time. The following section discusses the job creation potential of SMEs operating in PPP projects in detail.

Employment and growth by SMEs providing services to PPP projects: Figure 7 shows the number of employees employed by SMEs that provide services to PPP projects. The result show that, on average, the majority of SMEs that are contracted by PPP project companies employ between 0 and 20 employees $(30,8 \%)$, followed by those who employ 21 to $40(23,1 \%)$, and those employing more than 100 employees $(23,1 \%)$. This trend follows the one for the rand share of services outsourced to SMEs versus big firms, shown in Figure 3.

Figure 7: Number of employees employed by SMEs in PPP projects

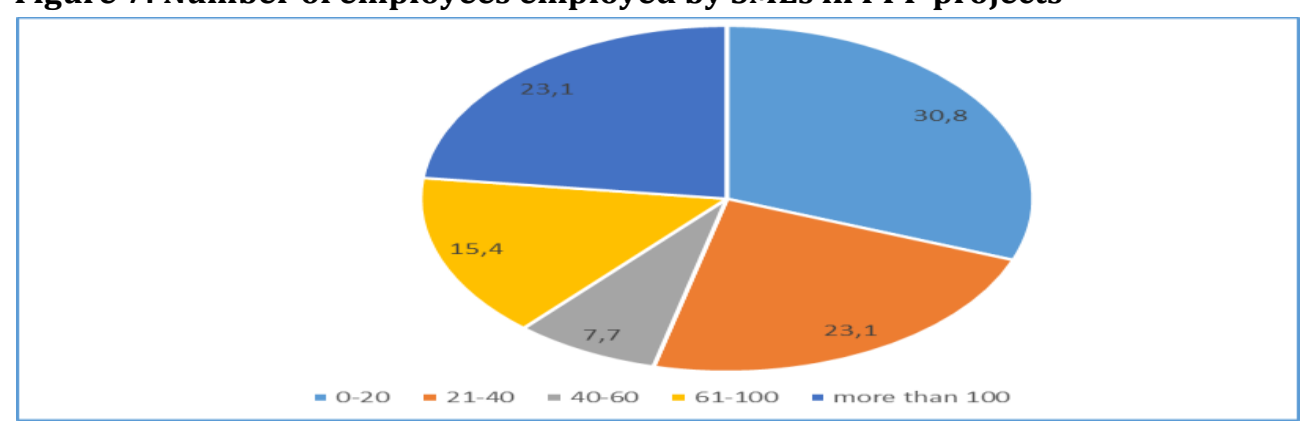

Source: Survey conducted by Author

Table 7 gives the number of people that the different SMEs employed in the beginning of their respective contracts with PPP firms and the current number of people who were still employed by the different SMEs during the research period. These employment figures do not include SMEs that provide services to PPP firms for a specific project, say not more than six months. Most of the SMEs that provided information on employment had a contract for at least three years and the figures presented here are for permanent employees. Eight PPP projects were covered by the employment figures, although other respondents refused to answer questions on employment. This translates to $57 \%$ of the PPP projects that comprised the study sample. SME1 to SME6 provide services to office blocks PPPs, SME7 provides service to prison PPP, SME8 to SME12 provide services to road PPPs, and SME13 provides services to a hospital PPP. There were no responses received from SMEs providing services to water and conservation PPP projects. It is clear from Table 7 that the number of people employed by the different SMEs increased during the contract period. It is also observed that SMEs that provided services to PPP projects for a longer period increased their number of employees by a bigger margin over the years. This shows that PPP projects have a potential to create jobs through the use of SMEs.

Table 7: Employment by SMEs in PPP projects

\begin{tabular}{lllllllllllllc}
\hline $\begin{array}{l}\text { Starting } \\
\text { period }\end{array}$ & SME & SME & SME & SME & SME & SME & iME & SME & SME & SME & SME & SME & SME \\
\hline Starting & 9 & 20 & 24 & 0 & 4 & 343 & 33 & 100 & 10 & 4 & 16 & 6 & 18 \\
employment $^{7}$ & & & & & & & & & & & & & \\
\hline
\end{tabular}

${ }^{5}$ There was no staff members employed in the beginning of the project.

${ }^{6}$ The figure under this SME represents a number of SMEs providing services to the PPP project. The researcher could not get disaggregated figure. 
Journal of Economics and Behavioral Studies (ISSN: 2220-6140)

Vol. 9, No. 6, pp. 67-89, December 2017

\begin{tabular}{|c|c|c|c|c|c|c|c|c|c|c|c|c|c|}
\hline $\begin{array}{l}\text { Current } \\
\text { employment- } \\
2015\end{array}$ & 15 & 36 & 36 & 2 & 4 & 350 & 65 & 200 & 36 & 100 & 107 & 60 & 24 \\
\hline $\begin{array}{l}\text { Percentage } \\
\text { increase (\%) }\end{array}$ & 67 & 80 & 50 & 100 & 0 & 2 & 97 & 100 & 260 & 2400 & 569 & 900 & 33 \\
\hline
\end{tabular}

Source: Survey conducted by the Author

SME 1=facility management, SME 2= cleaning, SME 3=catering, SME 4=CCTV, SME 5= Garden services, SME 6= combined services for office block, SME 7=asset maintenance in general, SME 8= road maintenance, rehabilitation and accident response, SME 9=security, SME 10=road maintenance, SME11=rehabilitation and accident response, SME 12= toll collection, SME13=security

Practice and challenges in fostering the use of SMEs by PPP firms: When respondents were asked whether their PPP firms outsource some of the services they need, $82 \%$ said yes, and $15 \%$ said their PPP firms do not outsource (see Figure 8a). It is worth noting that these PPP firms that outsource services do not only outsource their services to SMEs alone, but to both SMEs and big firms. Therefore the $82 \%$ represent services provided by both SMEs and big firms. Some of these PPP firms only outsource to big firms. When those respondents whose responses were no, were asked to give reasons why their PPP firms do not outsource to SMEs, the responses were that the extent of risk that can be transferred to SMEs can be overwhelming for many SMEs, while others said they had not ventured into this idea because the National Treasury PPP Unit first needed to be well-resourced and stabilised before PPP firms could consider using SMEs intensively. Others argued that the quality of work provided by some SMEs is not of a high standard, thus PPP firms are reluctant to employ SMEs, as most SMEs lack experience and capacity (see Figure 8b). It was also argued by the respondents that PPPs are too expensive for SMEs and the finances needed by SMEs to participate in PPP projects can be difficult to access for most SMEs. In the tourism sector, because of the remoteness of nature reserves, finding a suitable SME is a challenge, therefore in many cases PPPs struggle to find a suitable SME firm.

Figure 8: Practices and challenges in fostering the use of SMEs in PPPs

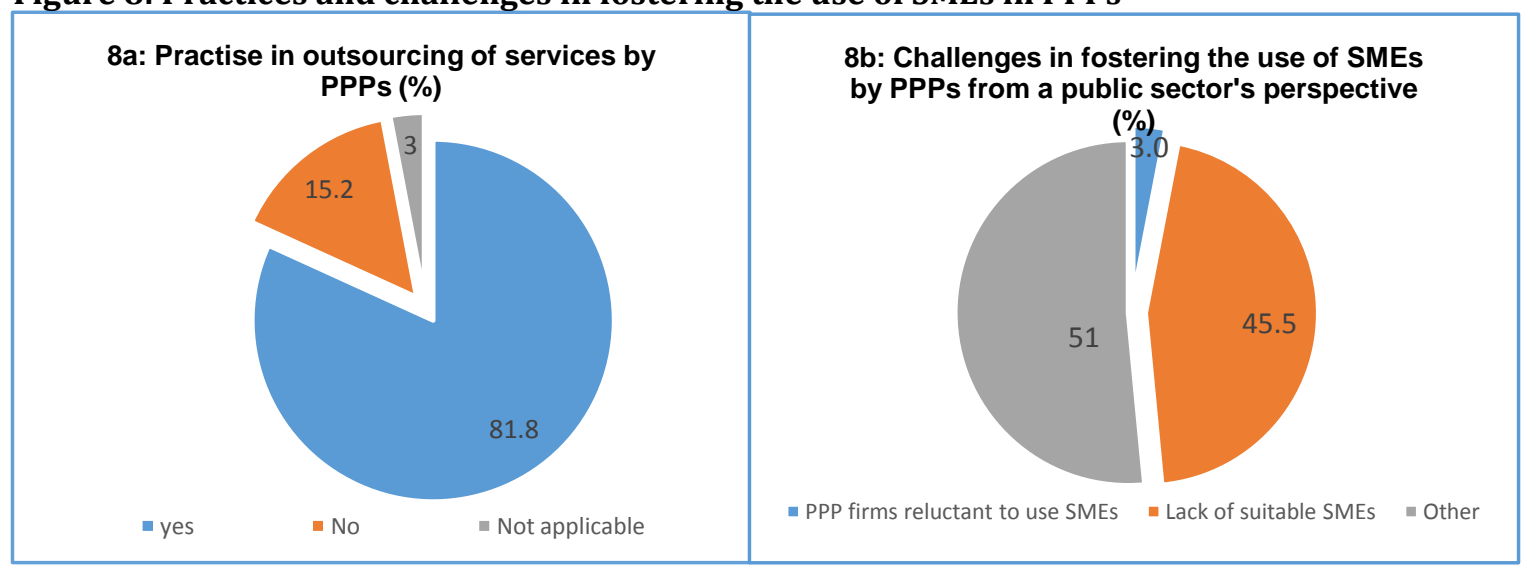

Source: Survey conducted by the Author

From the public sector perspective, the main challenge in improving the participation of SMEs in PPP projects was found to be the lack of suitable SMEs to provide the required services, due to the challenges mentioned earlier that SMEs lack skills and access to finance; as a result they may have difficulties in meeting the expectations of PPP firms in terms of service quality and delivery. Given the respondents' experience with PPP projects and the involvement of SMEs as HDI-owned companies in PPPs, public sector respondents argue that most of the SME companies are technically and financially weak. As a result, some of them opt for financial compensation and to be bought out of the project by big firms. Another argument made by public

${ }^{7}$ The starting operation date for SME1 to 5 and SME13 was 2010. For SME 6 was 2003, for SME 7 was 2002, for SME 8 was 1997 , and for SMEs 10,11,12 was 1997. 
sector respondents was that it is difficult for a big project to involve SMEs because that would mean to have a number of them coming together in order to have the capacity to deliver the service, which brings about new challenges. Other respondents mentioned reluctance of PPP firms to use SMEs as a challenge for increasing the participation of SMEs in the PPP market. This may be because of the poor quality service that PPP firms receive from SMEs, such as late delivery and substandard services. However, these challenges can be overcome by unbundling PPP projects to allow a fair participation of SMEs. Such unbundling will allow SMEs to execute tasks that they are capable to execute.

Improving the participation of SMEs in PPP projects: Respondents were asked how they thought the participation of SMEs in PPP projects could be improved, and also about who they thought should play a significant role in improving the participation of SMEs in PPP projects. With regards to improving the participation of SMEs in PPP projects, most respondents (mainly SMEs and public-sector respondents) thought the state should lead in this area by creating an environment conducive for both the SMEs and the PPP firms. The state should enforce the participation of SMEs by making it a mandatory requirement, through legislation or through the concessionaire contract, that any PPP project should have a significant SMEs content in it. This can be done in addition to the transformation requirement of the Preferential Procurement Regulations of 2001. The state should provide training to SMEs in areas where SMEs struggle, such as providing managerial skills and financial management skills. With regards to who should play a significant role in promoting the participation of SMEs in PPP projects, respondents opined that both the state and the PPP firms should play a significant role; however, the responsibility should start with the state. The state should start by ensuring that SMEs are able to access opportunities in PPP projects. This can be done through legislation. Table 8 summarises the survey responses on how the participation of SMEs in PPP projects could be improved and who respondents thought should play a significant role.

Table 8: Improving participation of SMEs in PPP projects

$\begin{array}{ll}\text { Respondents' opinions on how the participation of } & \text { Respondents' views on who should play a } \\ \text { SMEs in PPP projects can be improved (things to be } & \begin{array}{l}\text { significant role in improving the } \\ \text { participation of SMEs in PPP projects } \\ \text { done by government) }\end{array} \\ & \begin{array}{l}\text { between government and the PPP company } \\ \text { and why (things to be done by PPP firms) }\end{array}\end{array}$

Government should put mechanisms in place to give incentives to PPP companies who actively involve SMEs

SMEs need to acquire management skills in general, and financial management skills in particular, to ensure that problems are addressed as early as they emerge; such skills can be provided by the state

Government should put mechanisms in place to give preferential treatment to PPP companies who actively involve SMEs

Base all activities on business ethics, sound business principles and best practices. Business management, skills development and training in business intelligence should be a prerequisite for the increased participation of SMEs in PPP projects

A database of SMEs, ranked based on performance during the past five years, may assist concessionaires to select appropriate SME partners. PPP contracts should require the concessionaires to have a programme of skills transfer allowing SME participation to increase
The role of empowerment should be the task of both parties, as this can ensure a certain degree of credibility that will ensure SMEs are trained to successfully integrate and benefit from the PPP project

PPP company (concessionaire) must take responsibility for assisting SMEs to deliver services required by the concessionaire by helping SMEs with skill development and access to technology and finance.

The concessionaire should drive the process of SME participation in PPP projects and government should monitor progress

PPP operator needs to have good oversight skills to identify problems at an early stage so that the SME can be assisted not to get into trouble, particularly financially, due to nonperformance

All participants should play a role, especially the PPP company. The PPP company needs to make sure that it gets appropriate services or product from SMEs that can assist them in delivering the service as specified within the 
Respondents' opinions on how the participation of SMEs in PPP projects can be improved (things to be done by government)

during the period of the contract

The government's role should be to create the right environment for the SMEs to acquire the correct skills. The SMEs also need to put in effort on their side to acquire those skills

Government should ensure that SMEs take part in the forming of a concessionaire rather than being add-ons towards the end to satisfy government requirements More clear objectives to be set on what and how much of the work to be outsourced to SMEs and government to monitor compliance with these targets

Skills transfer, as well as policy development to integrate SMEs to the current PPP market system is a necessity Government should incentivise PPP companies, maybe through tax breaks, for using SMEs to provide some of their services

Government to assist with access to finance for SMEs to procure goods that can be delivered to the PPPs

PPP company should lead, but government should provide stringent policy and legislation to enforce compliance

Provide realistic requirements in PPP contracts and avoid over expectations; knowing what SMEs can and cannot do will be helpful

Government intervention should be embedded in the concessionaire contract and should not be construed as interference

Government should train SMEs about opportunities in PPP projects by publishing a list of PPP projects and associated opportunities for SMEs on its website

Source: Survey conducted by Author

The responses given by respondents in the above table show that most of the things that need to be done in order to increase the participation of SMEs in PPP projects need to be done by the state. Low participation of SMEs in PPP projects should not be blamed only on the failure of PPP firms, but should also be blamed on the government's failure to provide the right environment for PPP firms to use SMEs in PPP projects. The creation of such an environment involves the development of a clear policy on how SMEs should be involved in PPP projects. Such policy could assist PPP firms in engaging with SMEs for available opportunities within PPP projects. In many cases, initiatives fail because it is difficult for participating parties to bring the private sector and the public sector together, but PPPs are capable of doing that. This means that, by having a PPP project, the difficulty of bringing the private sector and the public sector together has already been overcome.

\section{Conclusion and Recommendations}

It is worth noting that, although linking SMEs with PPP projects is necessary, it is not sufficient for the development of the SME sector. To develop a sustainable SME sector requires other interventions, such as the promotion of an entrepreneurship culture and the development of social capital and networks, the reduction of red tapes and the creation of a more enabling environment, including political will to implement policy and 
improve public sector capacity to respond to the needs of SMEs, and the reduction of crime and corruption. Although a number of different interventions have been implemented in South Africa, what may be lacking is a cohesive approach to deal with SMEs challenges.

Recommendations: If the following recommendations are implemented, the use of SMEs by PPP firms would be enhanced and the fight against unemployment, poverty and inequality would be won to a certain extent. Linking SMEs to PPPs can increase the benefits of PPPs in society, as this may achieve two things at one go, namely: providing the needed infrastructure to the citizens, and developing the SME sector. The following is therefore recommended:

- Develop a policy to foster the use of SMEs in PPP projects: Government should introduce an incentivebased policy or insert a section in the existing policy and make it mandatory for PPP firms to use SMEs during both implementation and operational phases of PPP projects. Minimum requirements for SME participation in PPP projects should be clearly stated in the policy;

- Unbundle PPP projects: Given that PPP projects are big in nature and SMEs do not always have the technical and financial know-how to execute such projects, government should incentivise PPP firms to unbundle PPP projects into smaller but viable projects to allow ease of SME participation in PPPs. However, unbundling may hinder participation of big PPP firms in PPP projects as unbundling may increase PPP projects' implementation risks. Therefore incentive-based policy is paramount to mitigate for this unintended consequence;

- Put in place a coherent approach to government's institutional framework to support SMEs: Government must develop a coherent and cohesive approach that links together all the different government initiatives to support SMEs and ensure they support each other and avoid duplication of responsibilities. The policy should also clearly define the role of government and that of the PPP firm in developing SMEs;

- Award well performing PPP firms: PPP firms that go an extra mile in using SMEs, for example those that surpass the minimum requirement on using SMEs, should be rewarded, while those that only strive to meet the bare minimum requirement should be penalised; and lastly,

- Develop human capacity in PPPs within the public sector: In order to ensure that implementation of the proposed model is not hindered by lack of capacity within the public sector, it is recommended that PPP capacity building within government departments working on PPP projects should be given priority.

\section{References}

Abor, J. \& Quartey, P. (2010). Issues in SME development in Ghana and South Africa. [online] International Research Journal of Finance and Economics, 39, 218-228. Available online at: http/www.eurojournals.com/irjfe 39_39.pdf. Accessed on 25 March 2014.

African Development Bank. (2012). Bank financing to small and medium enterprises in East Africa: Findings of a survey in Kenya, Tanzania, Uganda and Zambia. Tunis: African Development Bank. Working Paper Series no. 146, March.

Aigbavboa, C. O. \& Thwala, W. D. (2014). Challenges facing black-owned small and medium construction companies: A case study on Nelspruit-Mbombela Municipality, South Africa. Journal of Economics and Behavioral Studies, 6(10), 771-778.

Akugri, S. M., Bagah, J. K. W. \& Wulifan, J. K. (2015). The contribution of small and medium scale enterprises to economic growth: A cross-sectional study of Zebilla in the Bawku West District of Northern Ghana. European Journal of Business and Management, 7(9), 262-274.

Al-Dairi, A., McQuaid, R. \& Adams, J. (2012). Entrepreneurship training to promote start-ups an innovation in Bahrain. International Journal of Innovation and Knowledge in Middle East and North Africa, 1(2), 179-210.

AL-Mubaraki, H. \& Aruna, M. (2013). Technology innovation for SME growth: A perception for the emerging economies. Journal of Economics and Sustainable Development, 4(3), 156-163.

Ansell, C. \& Gash, A. (2007). Collaborative governance in theory and practice. Journal of Public Administration Research and Theory, 18(4), 543-571. 
Ayyagari, M., Demirgúç-kunt, A. \& Vojislav, M. (2008). How important are financing constraints? The role of finance in the business environment. The World Bank Economic Review, 22(3), 483-516.

Banerjee, R. (2014). SMEs' financial constraints and growth. BIS working papers No.475. Basel: Bank of International Settlement.

Batool, S. A. \& Zulfiqar, S. (2011). The performance and structure of small and medium enterprises: empirical evidence from Pakistan. Pakistan Journal of Social Sciences (PJSS), 31(2), 433-447.

Brink, A., Cant, M. \& Ligthelm, A. (2003). Problems experienced by small businesses in South Africa. A paper for the Small Enterprise Association of Australia and New Zealand 16 ${ }^{\text {th }}$ Annual Conference, held in Ballarat, 28 September to 01 October 2003.

Cooke, F. L. (2000). Human resource strategy to improve organisational performance: A route for British firms. Working paper No.9, October.

Criscuolo, C., Gal, N. P. \& Menon, C. (2014). The dynamics of employment growth: New evidence from 18 countries. CEP Discussion paper No.1274. Centre for economic performance. London: London School of Economics and Political Sciences. June.

Elibariki, M. (2007).The impact of foreign direct investment on agricultural productivity and poverty reduction in Tanzania. MPRA Paper No. 3671, November.

European Commission. DG Enterprise and Industry. (2010). Evaluation of SMEs' access to public procurement markets in the EU (2009 update), September. Available online at: http://ec.europa.eu/smartregulation/evaluation/search/download.do;jsessionid

=lCF8TT1Nfy2MJwBDWQC1Jx8g8rXtjwDlhK1vqn8M1f32kYbpfBXQ!1601440011?documentId=4289 .Accessed on 15 April 2014.

Falkena, H., Abedian, I., Blottnitz, M., Coovadia, C., Davel, G. \& Madungandaba, J. (2000). Access to finance in South Africa: A supply-side regulatory review. Not published. Available online at: http.Accessed on 22 June 2013.

Falkena, H., Davel, G., Hawkins, P., Llewellyn, D., Luus, C. \& Masilela, E. (2004). Competition in South African banking. Task group report for the National Treasury and the South African Reserve Bank. Pretoria. Reserve Bank. Available online at: http.Accessed on 15 August 2012.

Fatoki, O. \& Odeyemi, A. (2010). Which new small and medium enterprises in South Africa have access to bank credit? International Journal of Business Management, 5(10), 128-136.

First National Bank. (2010). The entrepreneurial dialogues: State of Entrepreneurship in South Africa. Johannesburg: First National Bank. Accessed online at: https. Accessed on 12 July 2017.

Fjose, S., Grunfeld, L. \& Green, C. (2010). SMEs and growth in Sub-Saharan Africa: Identifying SME roles and obstacles to SME growth. MENON-publication No.14/2010, Oslo, June. Available online at:http://www.norfund.no/getfile.php/Documents/Homepage/Reports\%20and\%20.

presentations/Studies\%20for\%20Norfund/SME\%20and\%20growth\%20MENON\%20\%5BFINAL\%5 D.pdf. Accessed on 20 November 2014.

Hussain, I., Farooq, Z. \& Akhtar, W. (2012). SMEs' development and failure avoidance in developing countries through public private partnership. African Journal of Business Management, 96(4), 1581 - 1589.

Hussain, M. N. (2000). Linkages between SMEs and large industries for increased markets and trade: An African perspective. Economic research papers, No. 53. African Development Bank.

Joubert, C. S., Schoeman, N. J. \& Blignaut, J. N. (1999). Small, medium and micro-sized enterprises (SMMEs) and the Housing Construction Industry: A possible solution to South Africa's socio-economic problems. South African Journal of Economics and Management Science,2(1), 21-33. Available online at: http.Accessed on 23 September 2014.

Klein, M., Aaron, C. \& Hadjimichael, B. (2001). Foreign direct investment and poverty reduction. Policy Research Working Paper 2613. Washington DC: World Bank. June.

Kumar R. (2012). Human Resources Management and total quality management - An important aspect in the Bank. Global Journal of Interdisciplinary Social Sciences, 1(1), 14-20.

Lall A. (1992). Technological capabilities and industrialization. World Development, 20(2), 165-186.

Lee, J. W. (2001). Education for technology readiness: prospects for developing countries. Journal of Human Development, 2(1), 115-151.

Morgan, J. P. (2010). Global Entrepreneurial Monitor Report. Available online at: http://www.catalystforgrowth.org/wp-content/uploads/2014/02/ JPM_Dalberg_SME-Catalyst-forGrowth. pdf. Accessed on 28 February 2013. 
Morgan, J. P. (2012). The small and medium enterprises (SME) sector - Catalyst for growth in South Africa. Johannesburg: J. P. Morgan. Available online at http://www.catalystforgrowth.org/wpcontent/uploads/2014/02/JPM_Dalberg_SME-Catalyst-for-Growth.pdf. Accessed on 21 July 2014.

Mutsigwa, J. K. (2009). State-business partnership in poverty reduction: A case study of three public-private partnerships in Swaziland. Master of Philosophy thesis. University of Stellenbosch, Stellenbosch.

NEPAD Business Foundation. (2012). Infrastructure Africa business forum: Transforming Africa through Infrastructure. Press release. Rivonia-Johannesburg. NEPAD Business Foundation.

OECD. (2004). Facilitating SMEs' access to international markets: Promoting entrepreneurship and innovative SMEs in a global economy. Towards a more responsible and inclusive globalisation2ndOECD conference of ministers responsible for small and medium sized enterprises (SMEs).Istanbul, Turkey, 3-5 June.

OECD. (2006). The Athens action plan for removing barriers to SMEs access to international markets. OECDAPEC global conference. Athens, Greece, 6-8 November.

Paolo, U. (1992). Public-private partnerships: Success and failure factors for in-transition countries. New York: University Press of America.

Paton, C. (2013). Funds worth R4.6 trillion target State projects. Business Day, 24 June.

Pitt, M. M. \& Lee, L. F. (1980). The measurement and sources of technical inefficiency in the Indonesian weaving industry. Journal of Development Economics, 9, 43-64.

Republic of South Africa. Department of Public Works. (2009). Expanded public work programme. A 5 year report, 2004/05-2008/09. Pretoria: Department of Public Works.

Republic of South Africa. Department of Public Works. (2014). Phase of the expanded public works programme (EPWP): Briefing by Deputy Minister and Department. Available online at: http. Accessed on 16 June 2016.

Republic of South Africa. Department of Trade and Industry. (2004).National Small Business Amendment Act, No. 29.Pretoria: Department of Trade and Industry.

Republic of South Africa. National Credit Regulator. (2011). Literature review on small and medium enterprises' access to credit and support in South Africa. Midrand: National Credit Regulator.

Republic of South Africa. National Treasury. (2004a). PPP Manual Module 1: South African Regulations for PPPs. National Treasury Practice Note No. 02. Pretoria: National Treasury.

Republic of South Africa. Statistics South Africa. (2014a). Quarterly Labour Force Survey. Statistical release, PO 211, Quarter 4. Pretoria: Statistics South Africa.

Republic of South Africa. Statistics South Africa. (2014b). Poverty Trends in South Africa: An Examination of Absolute Poverty between 2006 and 2011. Report No. 03-10-06. Pretoria: Statistics South Africa.

Republic of South Africa. Statistics South Africa. (2016). Quarterly labour force survey, Quarter 3. 2016. Available online at: http://www.statssa.gov.za/publications/P0211/P02113rdQuarter 2016.pdf. Accessed on 18 December 2016.

Salleh, N. A., Kasolang, S. \& Jaffar, A. (2012). Green Lean TQM human resource management practices in Malaysian Automotive Companies. World Academy of Science, Engineering and Technology, 6(10), 2289-2295.

SBP. (2009). Small business development in South Africa. An SBP occasional paper, August. Available online at: www.sbp.org.za. Accessed on 26 June 2017.

SEDA. (2012). Analysis of the needs, state and performance of small and medium business in the Agriculture, Manufacturing, ICT and Tourism sectors in South Africa. Pretoria: SEDA.

Sharma, P. \& Gounder, N. (2012). Obstacles to bank financing of micro and small enterprises: Empirical evidence from the Pacific with some policy implications. Asia-Pacific Development Journal, 9(2), 4975.

Subrahmanya, M. H. (2012). Technological innovation in Indian SMEs: Need, status and policy imperatives. Current opinion in creativity, innovation and entrepreneurship, 1(2), 296-322.

Tan, H. W. \& Batra, G. (1996). Enterprise training in developing countries: Overview of incidence, determinants and productivity. Private sector development department occasion paper No.9. The World Bank.

Timm, S. (2012). How the state and private sector can partner to boost support to SMEs: Lesson from Chile and Malaysia. A report for the South African Department of Trade and Industry (the DTI) and TIPS, June. 
UNECA. (2009). Developing African agriculture through regional value chain. Economic Report on Africa. Addis Ababa, Ethiopia: UNECA.

UNIDO. (2007). Approaches to SMEs networking for market access. Available online at: http://www.unido.org/fileadmin/user_media/Services/PSD/Export_Consortia/NETWORKING_ENG. pdf. Accessed on 24 June 2013.

World Bank. (2004). Foreign direct investment (FDI) trends Looking beyond the current gloom in developing countries. Public Policy for the Private sector, Note No. 273, September. 